\title{
E-Teach : Mobile Application Teaching Administrative System Using Near Field CommunicationN (NFC)
}

\author{
Ferry $^{1}$, Dedy Prasetya Kristiadi ${ }^{2}$, Sutrisno $^{3}$ \\ ${ }^{1,2,3}$ Universitas Raharja, Banten, Indonesia
}

Ferry.sudarto@raharja.info,dedy.prasetya@raharja.info, sutrisno@raharja.info

\begin{abstract}
Teaching administration is a teacher's needs that are recorded or recorded into files stored by the school curriculum section. Teaching administration is in the form of lesson plans per semester made by the teacher to be applied based on the planned subject matter. Archiving of learning outcomes data and teaching materials is often ignored so that teachers do not provide subject matter according to the study plan and evaluation of learning outcomes is not satisfactory. In addition, the teacher administration file is a need for school accreditation which is a benchmark for the education office's assessment, which is a serious concern for schools in making reports in their work units. To reduce administrative errors, loss of data and the effectiveness of teaching services and assist teachers in managing lesson plans and evaluating learning outcomes, a tool that is able to provide solutions is needed. Near Field Communication, abbreviated as NFC, is a development tool for Bluetooth and RFID. NFC allows the phone to store important data securely and sent to other phones equipped with NFC or read by an NFC reader. In addition, this NFC allows mobile phones to be developed for the administration of school payments as well as giving class schedules to students. In this study, a teaching administration system based on Near Field Communication (NFC) has been developed using the Raspberry Pi as a microcontroller as well as a computer capable of applying web-based programs. Electronic teaching administration with NFC is expected to replace conventional teaching administration. The advantages of NFC-based ETeach are that it takes a short time to use, does not depend on internet access and is easy in delivering teacher administration to those in need. Study plan data processing and evaluation of student learning outcomes are faster, more accurate and integrated with the management of education providers.
\end{abstract}

Keywords: e-teach mobile, electronic teacher administration, android-based electronic teacher administration

\section{Introduction}

Teacher services at the time of teaching are preceded by making teaching administration in the form of lesson plans and syllabus which aims to guide students in carrying out learning activities for one semester to achieve predetermined learning outcomes.[1]. A teacher before carrying out teaching and learning activities must prepare learning administration, so that learning can take place smoothly. According to Saekhan Muchith, "an activity is planned in advance carefully and carefully, then the purpose of the activity will be more focused and more successful. [2]" In order to maintain quality and have continuity of learning, a complete teacher administration file is needed in the form of study plans, syllabus. learning, learning materials, reports on learning activities, reports on student abilities and reports on student attendance. This is in line with the strategic plan of the Ministry of National Education, namely the use of information technology media to improve the quality of educational data

ISSN : 2580-7250

Copyright (C) 2021 IJISTECH 
and develop information systems for stakeholders, especially computer-based ones, which absolutely must be mastered and implemented by every educator and education staff [3]. Data on student learning outcomes that have been carried out can be a reference for the next learning process. Data on learning outcomes and learning processes can also be carried out by classroom action research in order to find out the right learning patterns to improve the quality of learning outcomes [4]. However, the teacher's file which is recorded in the teaching administration file is stored in the archive and has a weakness in the form of damage or loss. Damage to teaching administrative files will make it difficult for teachers and schools as education providers. The threat of file damage affects learning, reporting student learning outcomes and reporting teacher performance. File damage and loss can be overcome by making electronic teaching administration. Privacy or confidentiality, integrity, authentication, access control, non-repudiation, and availability can be done using electronic teaching administration. The teaching administration data that has been entered by the administration section into the electronic teaching data can be accessed at any time when the teacher enters the school building. This availability condition can be met if there is an internet connection and the availability of server services where electronic teaching data is stored. This is in line with the school's enterprise architecture, namely information system development activities to achieve business process goals by maximizing company resources, IT investment and system development activities can be fulfilled [5].

The need for technology that is capable of off-line data retrieval and processing and allows data stored in mobile devices to be sent on a server for learning purposes is Near Field Communication (NFC) tag reader and raspberry pi. Through the NFC tag reader data can be retrieved and processed off-line, but at the same time as possible the data can be sent to the server for wider purposes. In addition, NFC-based teaching administration also allows teaching administration data to be used by learning services anywhere without depending on where the teaching administration was first created. Ease of accessing learning agenda information which ultimately helps in decision making such as student learning outcomes reports from subject teachers, student holidays, assignment assignments, student behavior reports. Several researches on electronic teaching administration were conducted by [6], [7], and [8].

\section{Research Methodology}

\subsection{Learning}

Learning is a teaching and learning process that involves teachers as educators and students as educated in an effort to achieve the expected goals. According to Sagala learning is teaching students to use educational principles and learning theories are the main determinants of educational success [9]. Meanwhile, learning is a process organized by the teacher to teach students how to learn to acquire and process knowledge, skills, and attitudes [10]. Learning administration is a history of student development and material that is recorded or not recorded is stored in a file in the form of electronic or non-electronic. If data storage is done electronically, it will require a computer using database management. So the notion of teaching administration is seen as an administrative system of providing education starting from student admissions, academic operations and student discharges [8]. Teaching administration data will be stored until the time when the data will be retrieved when needed to continue the education process and the school accreditation administration process. According to Suparlan, a teacher is someone who obtains a Decree (SK), either from the government, or the private sector to carry out his duties, and therefore has the right and obligation to carry out teaching and learning activities in educational institutions in schools [11]. 
There are several important things related to teaching administraition wamely: teaching plans,

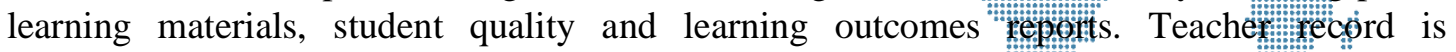
information that is recorded in written or electronic form about the teacher in carrying out the teaching and learning process. Teacher records are individual. Next is related to teaching management. Teaching management is "the process of processing student data which is supported by the teaching administration to produce useful information for carrying out management, financial and developmental responsibilities of students.

\subsection{Near Field Communication tag reader}

Smartphone technology continues to evolve with the addition of features that make it a multifunctional device. The Near Field Communication (NFC) tag is one of the features currently embedded in smartphones. NFC reader allows smartphones to communicate with other mobile devices without using the cellular network at a distance of about $4 \mathrm{~cm}[12]$ Near Field Communication (NFC) is a new short-range wireless connectivity technology, developed from the process of combining interconnection technology and non-contact identification. which exists. Communication between two NFC-enabled devices occurs when they are between 0 to $10 \mathrm{~cm}$ [13] In addition, NFC smartphones can read data stored in smart cards (NFC tags). Another advantage of NFC is that it is compatible with Bluetooth or wi-fi technology. NFC and Bluetooth are communication technologies with short communication range that have been integrated with mobile phones. NFC has a faster communication setup time than Bluetooth. Bluetooth devices need to run a manual process to identify the Bluetooth device to be connected, the connection between 2 NFC devices can be done instantly $(<0.1$ seconds) [13] with a communication radius closer than Bluetooth, less than $10 \mathrm{~cm}$. Maximum data transfer for NFC is $424 \mathrm{Kbps}$, lower than Bluetooth, which is $721 \mathrm{Kbps}$. However, NFC provides a higher level of security and makes it particularly suitable for crowded areas and compatible with existing RFID technologies. NFC has elemental advantages over RFID, which can be used for two-way communication and installed on smartphones [14] and equipped with devices capable of managing secure elements.

NFC is a subset of Radio Frequency Identification (RFID) technology, and NFC is a shortrange wireless communication technology, in which an NFC cell phone taps a few centimeters onto an NFC chip. NFC uses a high frequency of $13.56 \mathrm{MHz}$ and runs in various data transmission speeds such as $106 \mathrm{kbps}, 212 \mathrm{kbps}$, and $424 \mathrm{kbps}$. The NFC chip or NFC tag is made in a sticker formed from the antenna and IC, where the antenna will read the external sign from the NFC cellphone and activate the IC. NFC technology has been applied to mobile phones since 2012 and NFC mobile phones have been implemented in many mobile phone manufacturers such as Samsung, Huawei, Xiaomi, OnePlus, Motorola, LG, Nokia, Sony and HTC. Using NFC on the phone will help us when there is no internet access connection. Using a mobile phone equipped with NFC chip technology that can upload and download with your mobile phone, perform peer to peer communication.

\subsection{Proposed Idea}

The application architecture design presents the basic framework of the software system built. The web and android based Near Field Communication (NFC) based e-teach information system development architecture is shown in Figure 1. The system will be developed in schools interested in building teacher administration technology. Passive NFC will be installed on the school administration desk when the teacher makes attendance. NFCenabled or NFC-enabled phones will be marked as NFC passive and will provide a link that teachers or admin staff can use to get any information they want. NFC phones can connect to the system using a Wireless Access Point (WAP) to connect to the system. However, to be 
able to access the system, every NFC phone must download this memobile application on the Play Store and install it on the teacher's NFC cellphone and imened the identity including the teacher ID number. Furthermore, teachers: $c a n$ access sutiont data, study materials and student complaints. Students can also use this application to get reports on the learning outcomes of certain teachers, discuss difficulties in learning certain materials, and so on.

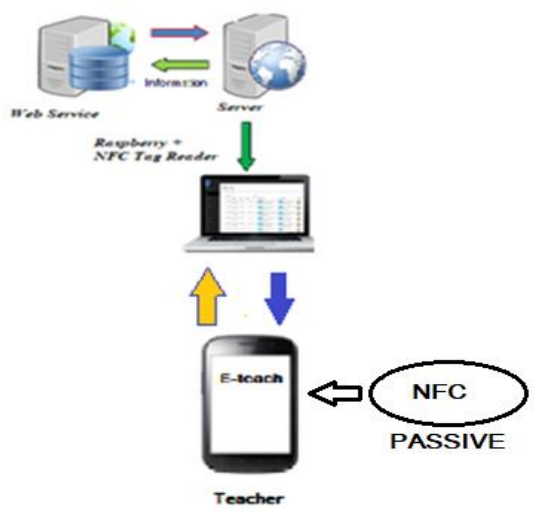

Figure 1. System Architecture Teacher Administration Application

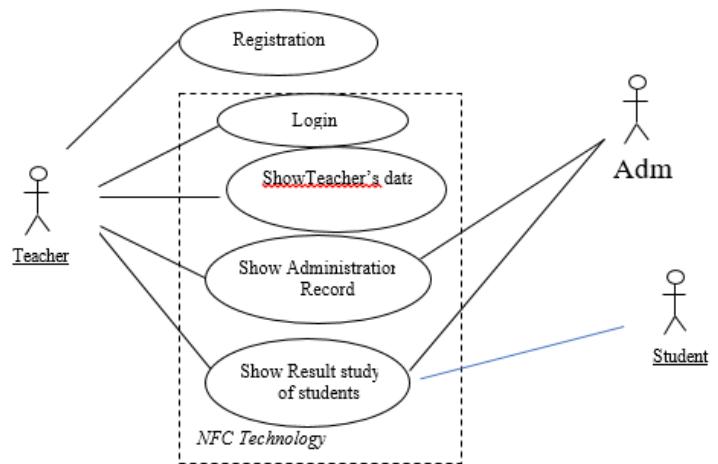

Figure 2. Use Case diagram

Figure 2 shows the use case activity of the teacher administration system where the use case activity in the dashboard box runs based on an NFC technology connection.However, this use case activity can be accessed online or without NFC technology.

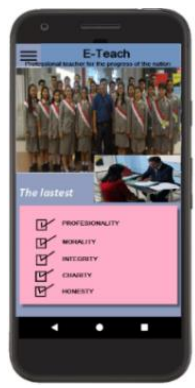

(a)

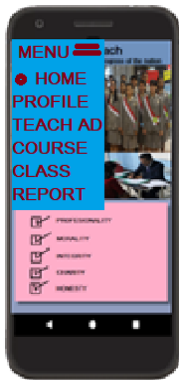

(b)

Figure 3. (a),(b) Main Menu User Interface 
Figure 3(a)(b) shows the main menu of the mobile application. os of teachers, school admins and students, they need to download this et teach mobule ap and install it on their NFC mobile app and register by entering thesin data like dâte 'of birth, address, occupation and contact number.

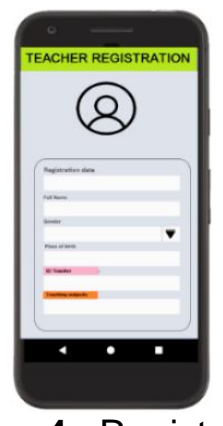

Figure 4. Registration

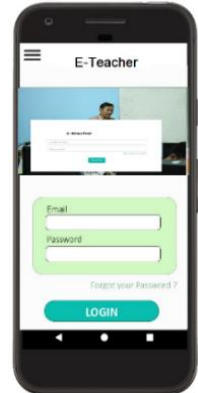

Figure 5. Login

Figure 4 shows the User Interface (UI) for registration as a new application user. After registration, they can login to the system by entering their email as Admin staff or teacher ID number or student ID, including password, where the UI can be seen in Figure 5.

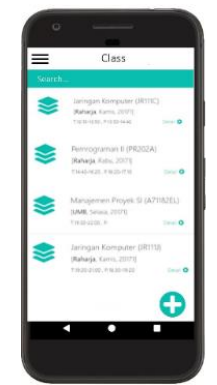

Figure 6. Menu Class and Session

Figure 6 shows the teacher's activities that have been carried out. This display will make it easier for teachers to send teaching administration to school admin staff which will be used as supporting documents for semester reporting needs.

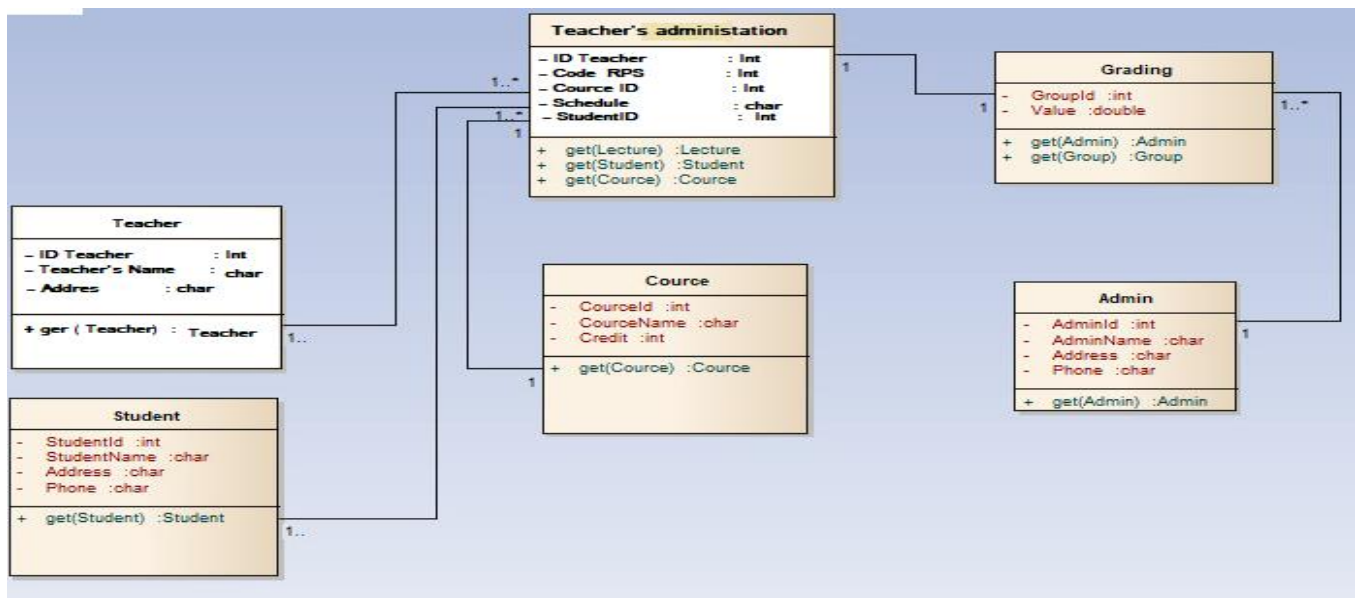

Figure 7. Class Diagram 
Figure 7 shows the design of the ESDM database model for the the implementation of this application where there are six database tables such as teachers teacher adwininititiotion, classes, subjects, students, admin. The teacher administration tâte contains foüt: attributes related to the RPS table, subjects and students.

\section{Conclusion}

The application of the E-teach mobile application will help both teachers and admin staff, where the admin can obtain information about the teaching carried out by the teacher. Meanwhile, teachers can carry out school administration such as: making lesson plans, learning schedules, making learning reports and evaluating the learning process that has been implemented. Students can access the material provided by the teacher through the admin computer. The use of this E-teach mobile application can avoid data loss, class vacancies and teacher unpreparedness to teach. In addition, supervision carried out by admin staff can ensure the completion of teacher teaching administration before the learning process is carried out. In addition, the use of NFC technology will provide smooth and fast access whenever an NFC mobile phone as NFC active can tag to a designated passive NFC.

Using the E-teach mobile application will help the school in preparing teacher administration documents for school accreditation and certification. Furthermore, as a school promotion, this application can be useful for people who want to send their children to school. In the future, the E-teach mobile application using NFC technology will be expanded to other activities such as monitoring teachers in conducting collaborative-based learning activities with fellow teachers, monitoring student activities in class, where students can get counseling about learning difficulties.

\section{References}

[1] Pemerintah Republik Indonesia. (2016). Peraturan Menteri Pendidikan dan Kebudayaan Republik Indonesia No. 22 Tahun 2016 tentang Standar Proses Pendidikan Dasar dan Menengah. Jakarta.

[2] Saekhan Muchith. (2008). Pembelajaran Kontekstual. Semarang: Rasail Media Group.

[3] Renstra kementrian pendidikan dan kebudayaan 2020-2024,hal 57 https://dikti.kemdikbud.go.id/wp-content/uploads/2020/10/RENSTRA KEMENDIKBUD-full-version.pdf

[4] Dedy Prasetya Kristiadi (2016),Meningkatkan Prestasi Belajar dengan Kooperatif Student Achievement Division(STAD) pada Pelajaran Diagnosa PC kelas XI TKJ SMK Bonavita,Jurnal Puslitjakdikbud,Volume 1, No.1 2016.pp 58-94

[5] Dedy Prasetya Kristiadi, (2017) Pengembangan Arsitektur Enterprise Administrasi Pendaftaran Dan Operasional Akademik Smk Bonavita Tangerang Dengan Metode Zahman Framework, 6(1),

[6] H. Suhada,Lukman Nulhakim,Kristiadi,D.P. Fery sudarto.(2019) Blended Learning Development In Islamic Religious Education Lessons Make Use of Web and Android,International Journal for Education and Vocational School,1(4), hal 428-433

[7] Kristiadi, D.P, Muhaimin, Sutrisno, Suwarto, (2019) The Effect of Adventure Video Games on the Development of Student's Character and Behavior, International Journal for Education and Vocational School,hal 330-334.

[8] Sutrisno,Kristiadi,DP. Dedi Iskandar,2017, Pengembangan Arsitektur Enterprise Administrasi Sma Santo Leo 2 Jakarta Dengan Metode The Open Group Architecture Framework (Togaf \}, Incomtech, Vol 6(1).

[9] Sagala, Syaiful. 2007. Konsep dan Makna Pembelajaran. Bandung: Alfabeta. Hal:61 
[10] Dimyati. Mudjiono. 2006. Belajar dan Pembelajaran. 157.

[11] Suparlan. (2006). Guru Sebagai Profesi. Yogyakarta: Hikayatefepblishing, 2006: 11.

[12] Dedy Prasetya Kristiadi, Muhaimin Hasanudin, Sutrisno,2021, Mobile Application of Electronic Medical Record (EMR) Systems using Near Field Communication (NFC) Technology, International Journal of Open Information Technologies,vol 9(10), hal 6872.

[13] S. Litchfield, "Enhancing your life and business by writing your own NFC tags," 710 2013. [Online]. Available: http :// allaboutwindowsphone.com / features / item/ 18498_Enhancing_your_life_and_busine.php.

[14] T. D. Lazzari, "Architecture \& Development of NFC Applications," Smart University, 2009 